University of Nebraska - Lincoln

DigitalCommons@University of Nebraska - Lincoln

USDA Forest Service / UNL Faculty Publications U.S. Department of Agriculture: Forest Service --

National Agroforestry Center

2013

\title{
A COMPARISON OF DEM-BASED INDEXES FOR TARGETING THE PLACEMENT OF VEGETATIVE BUFFERS IN AGRICULTURAL WATERSHEDS
}

\author{
Mike Dosskey \\ USDA Forest Service, mdosskey@fs.fed.us \\ Zeyuan Qiu \\ New Jersey Institute of Technology \\ Yang Kang \\ University of Science and Technology of China
}

Follow this and additional works at: https://digitalcommons.unl.edu/usdafsfacpub

Dosskey, Mike; Qiu, Zeyuan; and Kang, Yang, "A COMPARISON OF DEM-BASED INDEXES FOR TARGETING THE PLACEMENT OF VEGETATIVE BUFFERS IN AGRICULTURAL WATERSHEDS" (2013). USDA Forest Service / UNL Faculty Publications. 245.

https://digitalcommons.unl.edu/usdafsfacpub/245

This Article is brought to you for free and open access by the U.S. Department of Agriculture: Forest Service -National Agroforestry Center at DigitalCommons@University of Nebraska - Lincoln. It has been accepted for inclusion in USDA Forest Service / UNL Faculty Publications by an authorized administrator of DigitalCommons@University of Nebraska - Lincoln. 


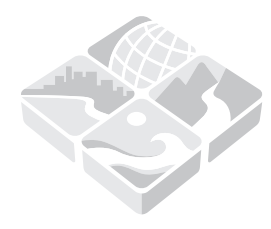

\title{
A COMPARISON OF DEM-BASED INDEXES FOR TARGETING THE PLACEMENT OF VEGETATIVE BUFFERS IN AGRICULTURAL WATERSHEDS ${ }^{1}$
}

\author{
Michael G. Dosskey, Zeyuan Qiu, and Yang Kang ${ }^{2}$
}

\begin{abstract}
Targeted placement of vegetative buffers may increase their effectiveness for improving water quality in agricultural watersheds. The use of digital elevation models (DEMs) enables precise mapping of runoff pathways for identifying where greater runoff loads can be intercepted and treated with buffers. Five different DEM-based targeting indexes were compared and contrasted for the degree to which they identify similar locations in watersheds: Flow Accumulation [S.K. Jenson and J.O. Domingue (1988). Photogrammetric Engineering and Remote Sensing 54:1593], Wetness Index [I.D. Moore, R.B. Grayson, and A.R. Ladson (1991). Hydrological Processes 5:3], Topographic Index [M.T. Walter, T.S. Steenhuis, V.K. Mehta, D. Thongs, M. Zion, and E. Schneiderman (2002). Hydrological Processes 16:2041], and the Water Inflow and Sediment Retention Indexes [M.G. Dosskey, Z. Qiu, M.J. Helmers, and D.E. Eisenhauer (2011b). Journal of Soil and Water Conservation 66:362]. The indexes were applied in two different watersheds, one in New Jersey and one in Missouri. Results showed that they all tend to target similar locations in both watersheds which traces to the importance of larger contributing area to the rankings by each index. Disagreement among indexes traces to other variables which enable more accurate targeting under particular hydrologic circumstances. Effective use of these indexes poses special challenges, including selecting an index that better describes the hydrologic circumstances in a watershed and is simple enough to use, ensuring the accuracy of the DEM, and determining a maximum index value for the appropriateness of vegetative buffers. When properly applied, each index can provide a standardized basis and effective spatial resolution for targeting buffer placement in watersheds.
\end{abstract}

(KEY TERMS: geospatial analysis; nonpoint source pollution; precision agriculture; runoff; source water protection; surface water hydrology; terrain analysis; watershed management.)

Dosskey, Michael G., Zeyuan Qiu, and Yang Kang, 2013. A Comparison of DEM-Based Indexes for Targeting the Placement of Vegetative Buffers in Agricultural Watersheds. Journal of the American Water Resources Association (JAWRA) 1-14. DOI: 10.1111/jawr.12083

\section{INTRODUCTION}

The effectiveness of vegetative buffers, such as filter strips and riparian forest buffers, for improving stream water quality in agricultural watersheds has long been regarded to be greater in some locations than in others within those watersheds (Qiu, 2003; Walter et al., 2007). Many approaches have been advanced for identifying more effective locations to target the installation of buffers and to enhance their environmental performance.

\footnotetext{
${ }^{1}$ Paper No. JAWRA-12-0218-P of the Journal of the American Water Resources Association (JAWRA). Received October 9, 2012; accepted February 27, 2013. (C) 2013 American Water Resources Association. Discussions are open until six months from print publication.

${ }^{2}$ Respectively, Research Ecologist (Dosskey), U.S. Forest Service, USDA National Agroforestry Center, 1945 N. 38th Street, Lincoln, Nebraska 68583; Associate Professor (Qiu), Department of Chemistry and Environmental Science, New Jersey Institute of Technology, Newark, New Jersey 07102; and Student (Kang), School for the Gifted Young and HUA Loo-Keng Elite Program in Mathematics, University of Science and Technology of China, Hefei, Anhui, China (E-Mail/Dosskey: mdosskey@fs.fed.us).
} 
One simple targeting model places vegetative buffers along the downhill margins of agricultural fields (e.g., NRCS, 2012). In these locations, they are more likely to intercept and retain pollutants in runoff. This model can be refined by focusing on cultivated and manure-applied fields, particularly ones that are steep and highly erodible (Dosskey et al., 2006) because these fields tend to contribute greater pollutant load to runoff than do other fields (e.g., Beaulac and Reckhow, 1982). Other simple models focus on landscape position, such as riparian areas through which runoff is expected to pass before entering streams (e.g., Welsch, 1991) or site conditions, such as wetlands which offer more favorable slope and soil chemistry for retaining and transforming pollutants in runoff (e.g., Rosenblatt et al., 2001). These examples represent the three characteristics of a welltargeted vegetative buffer: (1) adjacent to larger sources of pollutant load; (2) in the pathway of runoff flow from sources to streams; and (3) where site characteristics are more favorable for immobilizing pollutants with a buffer. The emergence of geographic information systems (GIS) technology and widespread availability of digital spatial databases on land uses (National Land Cover Database), streams (National Hydrography Dataset), soils (SSURGO Soil Survey), and wetlands (National Wetlands Inventory) have enhanced planners' ability to apply these simple categorical models in various combinations for targeting buffers within large landscapes.

These categorical models, however, lack sufficient spatial detail for effectively managing runoff with vegetative buffers. Resolution at the scale of whole fields, stream networks, and soil map units fail to account for field runoff that converges from larger source areas into concentrated flow paths that traverse only small portions of field margins and riparian zones (Dillaha et al., 1989; Dosskey et al., 2002, 2003; Pankau et al., 2012) and for wetlands that do not lie directly in those paths. Buffer area that intercepts only small portions of runoff will have negligible impact on stream water quality, whereas buffer area that intercepts very large, concentrated portions may be overwhelmed and ineffective (Dillaha et al., 1989).

To improve upon these simple categorical models, techniques must be applied that identify runoff source areas and pathways at a finer spatial scale. Newer targeting models employ topographic information in the form of digital elevation models (DEMs) which are used for determining source areas, runoff pathways, and slope conditions (e.g., Jenson and Domingue, 1988; Tarboton, 1997). Currently, the most common DEMs distinguish topographic patterns at horizontal resolutions of 10 and $30 \mathrm{~m}$ (Gesch, 2007), but can be as fine $1 \mathrm{~m}$ if developed from high-resolution imagery such as LiDAR (Xhardé et al., 2006). The simplest DEM-based targeting model would use only the DEM to identify where runoff flow converges from larger source areas and a buffer would intercept greater flow. Another simple targeting model is the Wetness Index (WNI) (Moore et al., 1991), which employs only the DEM to identify where flow converges from larger source areas to flatter slope locations. The WNI has been interpreted to gauge where more runoff accumulates and either infiltrates and deposits its sediment (Tomer et al., 2003 ) or raises the water table into interaction with the rooting zone (Burkart et al., 2004), depending upon local hydrologic circumstances. Buffers placed in locations having higher index values are more likely to reduce the pollutant load reaching a stream. The Topographic Index (TI) (Walter et al., 2002; Lyon et al., 2004) refines the WNI by additionally accounting for depth and permeability of the soil to more accurately gauge propensity for water table rise above the soil surface and generate erosive saturation-excess overland flow. The Water Inflow Index (WII) (Dosskey et al., 2011b) combines size of source area with soil infiltration properties to more accurately gauge where the amount of Hortonian, or infiltration excess, overland runoff from source areas would be greater, while its partner Sediment Retention Index (SRI) gauges the corresponding amount of sediment that would be deposited in a vegetative buffer at those locations. In all of these models, the DEM provides critical spatial details for managing agricultural runoff.

Conservation planners must choose between alternative targeting models. Some DEM-based targeting models were developed for use under specific hydrologic circumstances. However, as the size of source area is of central importance to all of the indexes and it is determined by similar methods, these indexes may produce similar results regardless of the actual hydrologic circumstances. If this is true, then the simpler of these indexes would be easier to apply and may produce adequate results for planning purposes. The objective of this study was to compare and contrast results using different DEM-based indexes for targeting buffers, and to evaluate their relative strengths and limitations for water quality planning.

\section{METHODS}

\section{Study Areas}

The targeting indexes were compared in two geographically distant and dissimilar watersheds, one in 


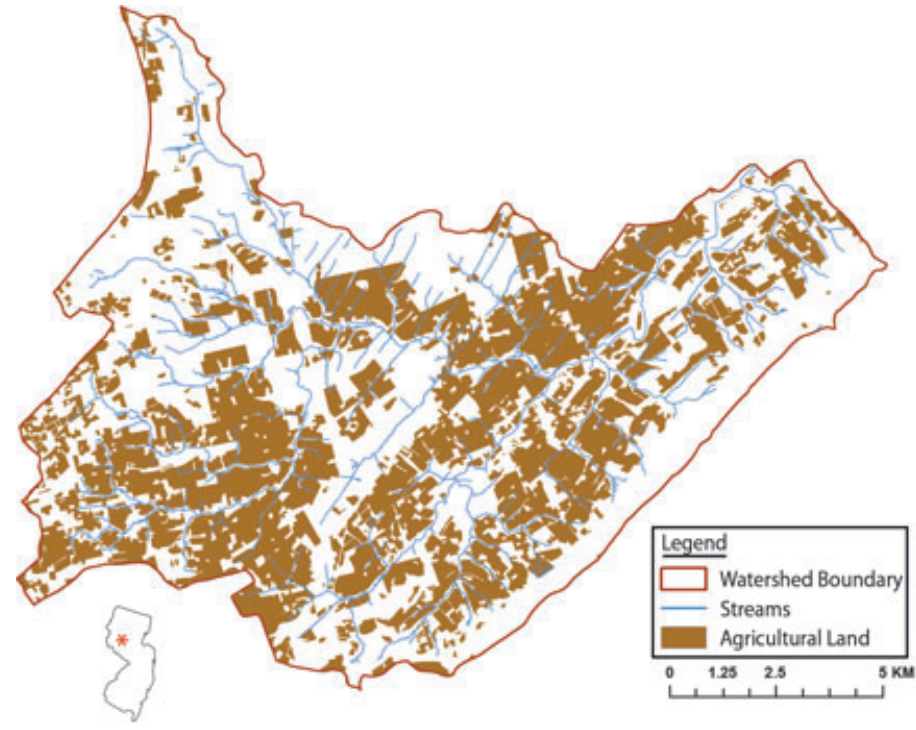

Neshanic River Watershed, New Jersey

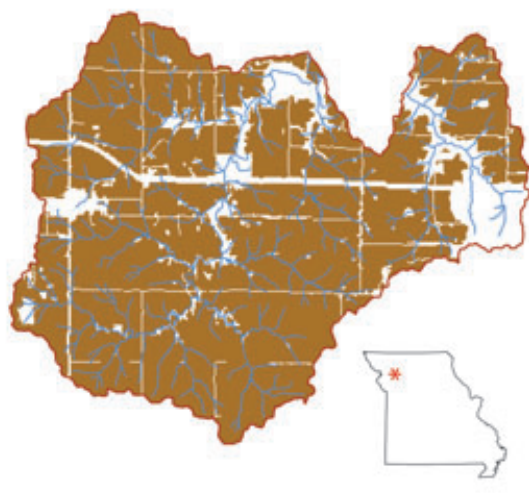

Cameron-Grindstone Watershed, Missouri

FIGURE 1. Location and Spatial Distribution of Agricultural Land in the Neshanic River Watershed, New Jersey, and the Cameron-Grindstone Watershed, Missouri.

New Jersey and the other in Missouri (Figure 1; Table 1). The New Jersey watershed is the $144 \mathrm{~km}^{2}$ Neshanic River watershed in Hunterdon and Somerset Counties in central New Jersey. The Neshanic River is a tributary in the Raritan River Basin which provides drinking water to over 1.75 million residents in the region (NJWSA, 2002). The Neshanic River has been listed as impaired for aquatic life, phosphorus, sediments, and pathogens from nonpoint sources (NJDEP, 2008, 2010). Impaired water quality has been linked to agricultural land use that covers about $40 \%$ of the watershed. Streamflow analysis suggests that soil saturation-excess overland runoff from agricultural areas could be an important process for mobilizing and transporting pollutants to streams in this watershed (NJDEP, 2011).

The Missouri watershed is the $67 \mathrm{~km}^{2}$ CameronGrindstone watershed in Dekalb and Clinton Counties in northwestern Missouri. Streams in this watershed drain to municipal drinking water reservoirs where there is concern about elevated levels of sediment, nutrients, and agricultural pesticides (MDNR, 2004). The watershed is predominantly under row crop cultivation and pasture. Soils in this watershed are developed from fine-textured loess which historically have experienced very high rates of rill and gully erosion (Nigh and Schroeder, 2002).

Three spatial datasets were used for calculating index values in each watershed: DEM, land cover, and soil survey. The DEMs used in this study were produced by the U.S. Geological Survey (USGS) from photogrammetric source data obtained in 1942 (Neshanic) and 1979 (Cameron) and compiled at 10-m grid
TABLE 1. General Characteristics of the Neshanic and Cameron-Grindstone Watersheds.

\begin{tabular}{|c|c|c|}
\hline \multirow[b]{2}{*}{ Characteristic } & \multicolumn{2}{|c|}{ Watershed } \\
\hline & Neshanic & $\begin{array}{l}\text { Cameron- } \\
\text { Grindstone }\end{array}$ \\
\hline Location & Central New Jersey & $\begin{array}{l}\text { Northwestern } \\
\text { Missouri }\end{array}$ \\
\hline $\begin{array}{l}\text { Physiographic } \\
\text { region }\end{array}$ & Piedmont Plains & $\begin{array}{l}\text { Dissected Till } \\
\text { Plains }\end{array}$ \\
\hline Topography & $\begin{array}{l}\text { Rolling hills; shallow, } \\
\text { wide valleys }\end{array}$ & $\begin{array}{l}\text { Rolling hills; } \\
\text { shallow, narrow } \\
\text { valleys }\end{array}$ \\
\hline Elevation range (m) & $31-210$ & $266-321$ \\
\hline Geology & Sedimentary, shale & $\begin{array}{l}\text { Loess over } \\
\text { glacial till }\end{array}$ \\
\hline Soils & Shallow, silt loam & $\begin{array}{l}\text { Deep, silt loam } \\
\text { over clay loam }\end{array}$ \\
\hline $\begin{array}{l}\text { Mean annual } \\
\text { precipitation }(\mathrm{cm})\end{array}$ & 122 & 94 \\
\hline Watershed area $\left(\mathrm{km}^{2}\right)$ & 144 & 67 \\
\hline $\begin{array}{l}\text { Total length of } \\
\text { channels }(\mathrm{km})^{*}\end{array}$ & 275 & 201 \\
\hline Perennial stream & 228 & 178 \\
\hline Other stream & 7 & - \\
\hline Canal/ditch & 5 & - \\
\hline Pipeline & 2 & - \\
\hline Artificial + connector & 33 & 23 \\
\hline $\begin{array}{l}\text { Drainage density } \\
\qquad\left(\mathrm{km} / \mathrm{km}^{2}\right)^{\dagger}\end{array}$ & 1.91 & 3.00 \\
\hline
\end{tabular}

*Based on the USGS National Hydrography Dataset 1:24,000 scale. 'Based on total length of channels.

resolution (7.5 min for Neshanic; 1/3 arc-second for Cameron). The DEM for the Neshanic watershed was obtained from the New Jersey Department of Environ- 
mental Protection (NJDEP) website (http://www.nj. gov/dep/gis/wmalattice.html). The DEM for the Cameron-Grindstone watershed was obtained from the USDA Natural Resources Conservation Service (NRCS) Geospatial Data Gateway (http://datagateway.nrcs.usda. gov). Land cover data for the Neshanic watershed were compiled by the NJDEP from aerial photographs taken in spring 2002 and was downloaded from the NJDEP website. Land cover data for the Cameron-Grindstone watershed was obtained from the National Land Cover Database (Fry et al., 2011) downloaded from the Multi-Resolution Land Characteristics Consortium website (http://www.mrlc.gov/nlcd2006.php). Soil survey data for both watersheds were obtained from the Soil Survey Geographic (SSURGO) database downloaded from the USDA-NRCS Soil Data Mart website (http://soildatamart.nrcs.usda.gov). Spatial analysis and index calculations were performed in ArcGIS Version 9.2 (ESRI, Redlands, California).

Agricultural lands in the study watersheds were defined as those which are both suitable for cultivation and recently in agricultural land use. Suitability for cultivation was defined as soil map units in Land Capability Classes 1 through 4 according to the SSURGO database. Recent agricultural land use was defined as cultivated crop, orchard, hay, and pasture in the land cover database. Each DEM grid cell was associated with the soil map unit and land use category occurring at the center point of each cell.

\section{Index Models}

Five DEM-based indexes were calculated for all grid cells in each watershed:

1. Flow Accumulation (FA) was determined for each grid cell by

$$
\mathrm{FA}=A,
$$

where $A$ is the contributing area draining to the grid cell (number of grid cells).

2. Wetness Index (WNI) was calculated for each grid cell by

$$
\mathrm{WNI}=\ln \left(A_{\mathrm{s}} \div \tan \beta\right),
$$

where $A_{\mathrm{s}}$ is the contributing area draining to the grid cell per unit length of a side of the grid cell $\left(\mathrm{m}^{2} \mathrm{~m}^{-1}\right)$ and $\beta$ is the slope angle of the cell (degrees). Slope values of zero were substituted with a value of 0.001 to avoid returning an undefined index value.

3. Topographic Index (TI) was calculated for each grid cell by

$$
\mathrm{TI}=\ln \left(A_{\mathrm{s}} \div\left[\tan \beta \cdot K_{\mathrm{sat}} \cdot D\right]\right),
$$

where $A_{\mathrm{s}}$ and $\beta$ are the same as for the WNI, $K_{\mathrm{sat}}$ is the saturated hydraulic conductivity of the soil profile (m/day) having depth $D(\mathrm{~m})$ above a layer that restricts percolation such as a bedrock or dense soil layer. Where there are multiple soil layers above a restrictive layer, $K_{\text {sat }}$ is the thickness-weighted mean conductivity of all soil layers above the restrictive layer. Slope values of zero were substituted with a value of 0.001 to avoid returning an undefined index value.

4. Water Inflow Index (WII) was calculated for each grid cell by

$$
\mathrm{WII}=0.81\left(A \cdot R \div K_{\mathrm{sat}}^{0.5}\right)^{0.8076},
$$

where $A$ is the contributing area (acres), $R$ is the rainfall-runoff erosivity factor (in.ft.tf.in/ac.hr.yr) of the Revised Universal Soil Loss Equation (RUSLE) (Renard et al., 1997), and $K_{\text {sat }}$ is the saturated hydraulic conductivity of the surface soil layer (in/h). The WII is calibrated for a freshly tilled field during a two-year, 24-h return-frequency storm event in units of $\mathrm{m}^{3}$ of water per $\mathrm{m}$ of land contour.

5. Sediment Retention Index (SRI) was calculated for each grid cell by

$$
\mathrm{SRI}=18.6\left(A \cdot R \cdot K \cdot[\mathrm{LS}] \div D_{50}\right)^{0.4333}
$$

where

$$
[\mathrm{LS}]=\left(A_{\mathrm{s}} \div 22.13\right)^{0.4}(\sin \beta \div 0.0896)^{1.3},
$$

$A$ and $R$ are the same as for the WII, $A_{\mathrm{s}}$ and $\beta$ are the same as for the WNI and TI, $K$ is the soil erodibility factor ( $t /$ ac EI) of RUSLE, and $D_{50}$ is the median particle diameter $(\mathrm{mm})$ of the surface soil layer which is assigned to its soil texture class according to Rawls and Brakensiek (1983). The SRI is calibrated for $\mathrm{kg}$ of sediment retained per $\mathrm{m}$ of land contour by a $12-\mathrm{m}$ wide grass buffer below a freshly tilled field during a two-year, 24-h return-frequency storm event.

Contributing area $(A)$ and specific contributing area $\left(A_{\mathrm{s}}\right)$ for each cell were determined for the WNI and TI indexes according to Qiu (2009) using the open-source extension TauDEM Version 3.1 (Tarboton, 2005). Corresponding values for WII and SRI indexes were determined according to Dosskey et al. (2011b) using the ArcGIS Flow Accumulation function which employs the algorithm of Jenson and Domingue (1988). Values for FA were also determined using the ArcGIS Flow Accumulation function. Slope of all grid cells was determined using the ArcGIS Slope function. The soil attributes, $K, K_{\text {sat }}$, and soil texture class, were determined from soil attribute 
tables in SSURGO for the soil map unit associated with the center point of each grid cell. Values for $R$ were estimated from Renard et al. (1997) to be 182 for the Cameron-Grindstone watershed and 155 for the Neshanic watershed.

\section{Method of Comparison}

The indexes were computed for all grid cells in the study watersheds. Postprocessing eliminated all nonagricultural grid cells from further analysis. Also, eliminated were grid cells that returned undefined values for the WNI and TI indexes because they had zero contributing area $\left(A_{\mathrm{s}}=0\right)$.

Assessment was made of the degree to which grid cells were ranked similarly by the different indexes. Pairwise comparisons were made of the number of grid cells comprising the highest ranking 5, 10, 15, and $20 \%$ of total cells that also were in the corresponding ranking set for the other index. These ranking percentages represent practical planning goals for vegetative buffer installation in agricultural watersheds. A high degree of correspondence is indicated by a high proportion of grid cells that are ranked highly by one index that were also highly ranked by the other index. The nonparametric kappa statistic (Fleiss et al., 2003) was also computed for each pairwise comparison as a statistical measure of agreement beyond chance for the degree to which two indexes place grid cells into and outside the same ranking group. Both the comparative grid-cell counts and kappa values were computed using the opensource $\mathrm{R}$ program (Version 2.15, The $\mathrm{R}$ Project for Statistical Computing, http://www.r-project.org).

The relative importance of contributing source area to the rankings by each index was assessed by the level of statistical agreement between FA, the definition of contributing area, and each of the other indexes. All results were compared and contrasted in terms of soil and site conditions that are favored for targeting by each index.

\section{RESULTS}

\section{Range of Index Values}

In the Neshanic watershed, there were 566,016 grid cells (5,660 ha) classified as agricultural and had nonzero contributing source area. For this set of grid cells, each index produced a wide range of values: WNI ranged from slightly greater than 0 to 25.7 ; TI from slightly greater than 0 to 26.7; WII from 0 to
173,048; SRI from 0 to 479,885 ; and FA ranged from 0 to $1,429,396$. The FA counts are larger than the total number of cells for which indexes were calculated because it counts nonagricultural cells that flow into agricultural cells. This disparity is greatest in the Neshanic watershed where forest and urban areas that occupy $60 \%$ of the watershed are interspersed with agricultural land. In the CameronGrindstone, agricultural lands dominate throughout the whole watershed.

In the Cameron-Grindstone watershed, there were 540,349 grid cells (5,403 ha) classified as agricultural and had nonzero contributing source area. For this set of grid cells, each index produced a wide range of values: WNI ranged from 3.7 to 22.3 ; TI from 3.8 to 32.2; WII from 0 to 114,518 ; SRI from 0 to 190,092 ; and FA from 0 to 545,011 .

The top 5, 10, 15, and $20 \%$ of grid cells by each index were subsets of the total range of values (Tables 2 and 3). Unequal numbers of cells for each index within these percentage ranges is due to cutoff percentages occurring at values having multiple cells with identical values. The cutoff was then moved to the next higher or lower value, whichever required the smallest number of cells being dropped or added. Consequently, the cutoff targets were not exactly at $5,10,15$, and $20 \%$, but were very close.

\section{Distribution of Index Values}

For both watersheds, the top 5\% of all indexes covered the majority of the range of index values. This is because all indexes are sensitive to contributing area and cells in the top 5\% of index values had contributing area cell counts ranging over four to five orders of magnitude, from 57 to $1,429,396$ in the Neshanic watershed and from 78 to 545,011 in the Cameron-Grindstone watershed (Tables 2 and 3). The largest cell counts correspond to the number of cells upstream of stream channel cells which occur near the watershed outlets and are not classified as either water or forest in the land cover dataset. The cell counts and index values decrease as one moves up the channel, decreasing substantially as larger tributaries are passed. This contrasts with the succeeding $15 \%$ of grid cells for which cell counts ranged only from 15 to 57 in the Neshanic watershed and from 11 to 78 in the Cameron-Grindstone watershed.

\section{Correspondence between Indexes}

For both study watersheds, there was a wide range in the degree of agreement between indexes for the 
TABLE 2. Number of Agricultural Grid Cells in the Neshanic Watershed, New Jersey, Ranked in the Top

(a) 5, (b) 10, (c) 15, and (d) 20\% of One Index That Are Also Ranked in the Corresponding Set by the Other Index for Each Pair of Digital Elevation Models-Based Targeting Indexes.

\begin{tabular}{|c|c|c|c|c|c|c|c|c|}
\hline Index & $\%$ of Area & Range of Values & Number of Grid Cells & FA & WNI & TI & WII & SRI \\
\hline \multicolumn{9}{|c|}{ (a) Top 5\% } \\
\hline FA & 5 & $57-1,429,396$ & 28,434 & - & & & & \\
\hline WNI & 5 & $10.24-25.7$ & 28,301 & 14,969 & - & & & \\
\hline TI & 5 & $10.88-26.7$ & 28,301 & 13,714 & 22,033 & - & & \\
\hline WII & 5 & $57.9-173,048$ & 28,260 & 26,262 & 14,833 & 13,877 & - & \\
\hline $\begin{array}{l}\text { SRI } \\
\text { (b) Top }\end{array}$ & 5 & $747-479,885$ & 28,301 & 21,342 & 10,994 & 10,228 & 20,800 & - \\
\hline FA & 10 & $29-1,429,396$ & 57,206 & - & & & & \\
\hline WNI & 10 & $9.27-25.7$ & 56,602 & 29,135 & - & & & \\
\hline TI & 10 & $9.91-26.7$ & 56,602 & 26,665 & 40,812 & - & & \\
\hline WII & 10 & $33.1-173,048$ & 56,542 & 51,358 & 29,096 & 27,493 & - & \\
\hline $\begin{array}{l}\text { SRI } \\
\text { (c) Top }\end{array}$ & 10 & $507-479,885$ & 56,602 & 42,187 & 20,221 & 19,279 & 40,342 & - \\
\hline FA & 15 & $20-1,429,396$ & 85,333 & - & & & & \\
\hline WNI & 15 & $8.82-25.7$ & 84,903 & 45,319 & - & & & \\
\hline TI & 15 & $9.38-26.7$ & 84,903 & 41,143 & 59,492 & - & & \\
\hline WII & 15 & $24.1-173,048$ & 84,174 & 77,012 & 45,240 & 42,261 & - & \\
\hline $\begin{array}{l}\text { SRI } \\
\text { (d) Top }\end{array}$ & 15 & $401-479,885$ & 84,903 & 64,447 & 31,644 & 30,342 & 61,457 & - \\
\hline FA & 20 & $15-1,429,396$ & 115,703 & - & & & & \\
\hline WNI & 20 & $8.51-25.7$ & 113,204 & 63,750 & - & & & \\
\hline TI & 20 & $9.01-26.7$ & 113,204 & 57,689 & 78,873 & - & & \\
\hline WII & 20 & $18.9-173,048$ & 112,939 & 104,349 & 63,290 & 59,629 & - & \\
\hline SRI & 20 & $338-479,885$ & 113,204 & 88,536 & 45,284 & 43,696 & 84,617 & - \\
\hline
\end{tabular}

Notes: FA, Flow Accumulation; WNI, Wetness Index; TI, Topographic Index; WII, Water Inflow Index; SRI, Sediment Retention Index.

TABLE 3. Number of Agricultural Grid Cells in the Cameron-Grindstone Watershed, Missouri, Ranked in the Top (a) 5, (b) 10, (c) 15, and (d) 20\% of One Index That Are Also Ranked in the Corresponding Set by the Other Index for Each Pair of Digital Elevation Models-Based Targeting Indexes.

\begin{tabular}{|c|c|c|c|c|c|c|c|c|}
\hline Index & $\%$ of Area & Range of Values & Number of Grid Cells & FA & WNI & $\mathbf{T I}$ & WII & SRI \\
\hline \multicolumn{9}{|c|}{ (a) Top 5\% } \\
\hline FA & 5 & $78-545,011$ & 26,968 & - & & & & \\
\hline WNI & 5 & $11.2-22.3$ & 27,018 & 17,288 & - & & & \\
\hline $\mathrm{TI}$ & 5 & $13.6-32.2$ & 27,018 & 17,423 & 22,165 & - & & \\
\hline WII & 5 & $134-114,518$ & 27,009 & 25,443 & 17,165 & 17,447 & - & \\
\hline \multicolumn{8}{|c|}{ (b) Top $10 \%$} & - \\
\hline FA & 10 & $23-545,011$ & 54,530 & - & & & & \\
\hline WNI & 10 & $9.65-22.3$ & 54,035 & 33,574 & - & & & \\
\hline TI & 10 & $12.1-32.2$ & 54,035 & 33,207 & 43,309 & - & & \\
\hline WII & 10 & $49.5-114,518$ & 54,128 & 49,301 & 32,870 & 33,148 & - & \\
\hline $\begin{array}{l}\text { SRI } \\
\text { (c) Top }\end{array}$ & 10 & $404-190,093$ & 54,035 & 43,667 & 26,779 & 26,863 & 43,877 & - \\
\hline FA & 15 & $14-545,011$ & 83,470 & - & & & & \\
\hline WNI & 15 & $8.95-22.3$ & 81,053 & 51,561 & - & & & \\
\hline TI & 15 & $11.4-32.2$ & 81,053 & 50,441 & 62,116 & - & & \\
\hline WII & 15 & $33.6-114,518$ & 79,182 & 73,301 & 48,696 & 49,340 & - & \\
\hline $\begin{array}{l}\text { SRI } \\
\text { (d) Top }\end{array}$ & 15 & $314-190,093$ & 81,053 & 63,240 & 37,952 & 38,947 & 62,881 & - \\
\hline FA & 20 & $11-545,011$ & 108,398 & - & & & & \\
\hline WNI & 20 & $8.51-22.3$ & 108,070 & 68,701 & - & & & \\
\hline TI & 20 & $11.0-32.2$ & 108,070 & 67,263 & 80,321 & - & & \\
\hline WII & 20 & $26.8-114,518$ & 107,605 & 93,332 & 65,452 & 68,591 & - & \\
\hline SRI & 20 & $266-190,093$ & 108,070 & 82,880 & 50,291 & 52,577 & 84,229 & - \\
\hline
\end{tabular}

Notes: FA, Flow Accumulation; WNI, Wetness Index; TI, Topographic Index; WII, Water Inflow Index; SRI, Sediment Retention Index. 
TABLE 4. Table 4Kappa Values for Each Pairwise Comparison of Digital Elevation Models-Based Indexes for the Top Ranking 5, 10, 15, and $20 \%$ of Cells in Each Index for the (a) Neshanic Watershed and (b) Cameron-Grindstone Watershed. Kappa values greater than 0.75 or so suggest excellent agreement beyond chance, values between about 0.75 and 0.40 suggest good to fair agreement, and values below 0.40 suggest poor agreement (Fleiss et al., 2003).

\begin{tabular}{|c|c|c|c|c|}
\hline Comparison & $5 \%$ & $10 \%$ & $15 \%$ & $20 \%$ \\
\hline \multicolumn{5}{|c|}{ (a) Neshanic Watershed } \\
\hline $\mathrm{FA} \times \mathrm{WII}$ & 0.93 & 0.89 & 0.89 & 0.89 \\
\hline $\mathrm{WII} \times \mathrm{SRI}$ & 0.72 & 0.68 & 0.68 & 0.69 \\
\hline $\mathrm{FA} \times \mathrm{SRI}$ & 0.74 & 0.71 & 0.71 & 0.72 \\
\hline $\mathrm{WNI} \times \mathrm{TI}$ & 0.77 & 0.69 & 0.65 & 0.62 \\
\hline $\mathrm{FA} \times \mathrm{WNI}$ & 0.50 & 0.46 & 0.45 & 0.45 \\
\hline $\mathrm{WII} \times \mathrm{WNI}$ & 0.50 & 0.46 & 0.45 & 0.45 \\
\hline $\mathrm{WII} \times \mathrm{TI}$ & 0.46 & 0.43 & 0.41 & 0.41 \\
\hline $\mathrm{FA} \times \mathrm{TI}$ & 0.46 & 0.41 & 0.39 & 0.38 \\
\hline $\mathrm{WNI} \times \mathrm{SRI}$ & 0.36 & 0.29 & 0.26 & 0.25 \\
\hline $\mathrm{TI} \times \mathrm{SRI}$ & 0.33 & 0.27 & 0.24 & 0.23 \\
\hline \multicolumn{5}{|c|}{ (b) Cameron-Grindstone Watershed } \\
\hline $\mathrm{FA} \times \mathrm{WII}$ & 0.94 & 0.90 & 0.88 & 0.83 \\
\hline $\mathrm{WII} \times \mathrm{SRI}$ & 0.85 & 0.79 & 0.75 & 0.73 \\
\hline $\mathrm{FA} \times \mathrm{SRI}$ & 0.83 & 0.78 & 0.73 & 0.71 \\
\hline $\mathrm{WNI} \times \mathrm{TI}$ & 0.81 & 0.78 & 0.73 & 0.68 \\
\hline $\mathrm{FA} \times \mathrm{WNI}$ & 0.62 & 0.58 & 0.56 & 0.54 \\
\hline $\mathrm{WII} \times \mathrm{WNI}$ & 0.61 & 0.56 & 0.54 & 0.51 \\
\hline $\mathrm{WII} \times \mathrm{TI}$ & 0.63 & 0.57 & 0.55 & 0.55 \\
\hline $\mathrm{FA} \times \mathrm{TI}$ & 0.63 & 0.57 & 0.54 & 0.53 \\
\hline $\mathrm{WNI} \times \mathrm{SRI}$ & 0.50 & 0.44 & 0.37 & 0.33 \\
\hline $\mathrm{TI} \times \mathrm{SRI}$ & 0.51 & 0.44 & 0.39 & 0.36 \\
\hline
\end{tabular}

Notes: FA, Flow Accumulation; WNI, Wetness Index; TI, Topographic Index; WII, Water Inflow Index; SRI, Sediment Retention Index.

grid cells that ranked in the top 5, 10, 15, and $20 \%$ ranges. In both watersheds, the highest correspondence occurred between FA and WII for all four toppercentage ranges, where $87-94 \%$ of cells within a range of one index were also in the same range by the other index (Tables 2 and 3) and kappa values ranged from 0.83 to 0.94 suggesting excellent agreement (Table 4). The lowest correspondence was between SRI and both WNI and TI for all four toppercentage ranges, where $34-53 \%$ of cells within a range of one index were also in the same range by the other index and kappa values ranged from 0.23 to 0.50 suggesting poor to fair agreement. There was also good to excellent correspondence between SRI and both FA and WII (kappa $=0.68-0.85)$ and between TI and WNI (kappa =0.62-0.81). All other pairwise combinations had only fair to good agreement $($ kappa $=0.38-0.63)$.

Correspondences (Tables 2 and 3) and statistical agreements (Table 4) differed between study watersheds in only two ways. First, correspondences and kappa values decreased for all index comparisons as the percentage range that was evaluated increased, but to different degrees in each watershed. For example, kappa values declined an average of 0.07 (range
0.02-0.15) between comparisons of the top 5\% and comparisons of the top $20 \%$ of index values in the Neshanic watershed and declined an average of 0.12 (range 0.08-0.17) for these same comparisons in the Cameron-Grindstone watershed (Table 4). Second, correspondences and statistical agreements were overall higher in the Cameron-Grindstone watershed than in the Neshanic watershed. Kappa values ranged from $(-0.01)$ to 0.18 higher and averaged 0.10 higher for the Cameron-Grindstone watershed than for the Neshanic watershed. All other patterns among indexes were very similar for both watersheds.

\section{DISCUSSION}

\section{Similarities and Differences in Results among DEM- Based Indexes}

In general, a fair to high degree of agreement was found among results of DEM-based targeting indexes. Most of the agreement traces to the importance of contributing source area in the rankings by each index. For example, FA and WII provided nearly identical results for targeting purposes in the study watersheds and FA was not much different from SRI. These results reflect that larger source area correlates very strongly with larger overland runoff volume and the potential for retaining sediment from that runoff with a buffer. Although there was only fair agreement between FA and both WNI and TI on a pixel-by-pixel basis, all of the indexes nevertheless produced results that generally resemble the natural stream network on agricultural land in the study watersheds (Figures 2 and 3).

Disagreement between indexes traces mainly to other variables and equation structures that are intended to more accurately describe buffer function under specific hydrologic circumstances and site conditions (Table 5). For example, TI has been field validated for areas having shallow, permeable soils where runoff from source areas is transported toward streams through subsurface lateral flow (Schneiderman et al., 2007; Easton et al., 2008). In contrast, WII and SRI were derived from the process-based model VFSMOD$\mathrm{W}$ which has been validated for conditions where runoff from source areas is overland and infiltration is limited only by the permeability of surface soil (Muñoz-Carpena and Parsons, 2012). The SRI index goes further to describe sediment retention whereas the other indexes focus only on water supply and implications for pollutant mitigation have to be inferred. These differences between models can explain why agreement was poor between SRI and TI. 

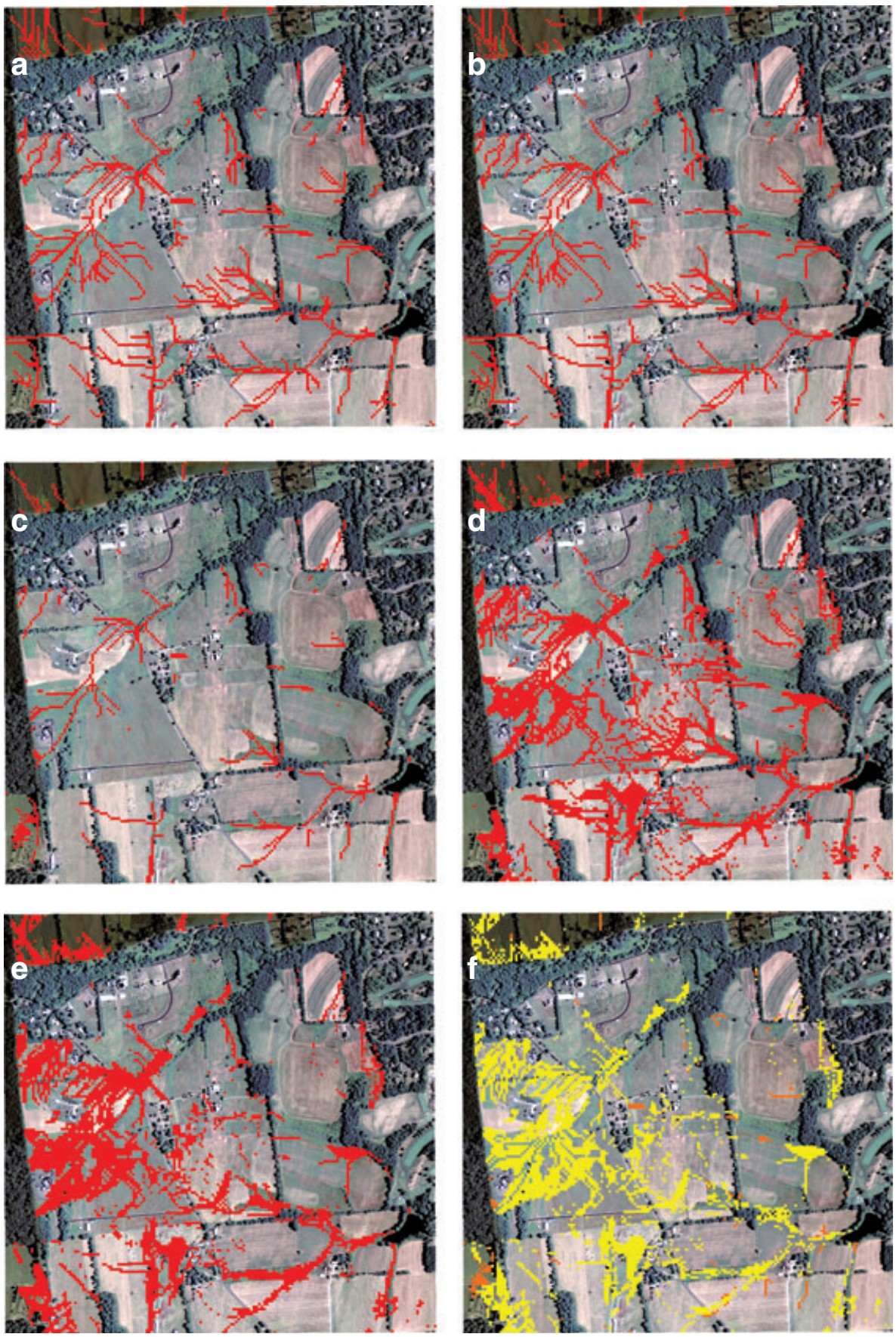

FIGURE 2. Aerial View of a $1 \mathrm{mi}^{2}\left(2.6 \mathrm{~km}^{2}\right)$ Portion of the Neshanic River Watershed, New Jersey, Showing Locations Identified in the Top 10\% of Index Values in That Watershed (in red) Using: (a) FA, (b) WII, (c) SRI, (d) WNI, and (e) TI. Photo (f) shows locations that were identified by TI but not by SRI (in yellow) and identified by SRI but not by TI (in orange).

Further disagreement can also be attributed to differences in the calculation of contributing area between Tarboton's (2005) D-infinity algorithm and Jenson and Domingue's (1988) D-8 algorithm. The D-infinity algorithm was used to calculate WNI and TI indexes, whereas the D-8 algorithm was used to calculate the FA, WII, and SRI indexes. Differences in the results between these two algorithms, however, have been shown to be small for source areas larger than a specific catchment area $\left(A_{\mathrm{s}}\right)$ of about $100 \mathrm{~m}^{2} \mathrm{~m}^{-1}$ (Tarboton, 1997) which translates in this study to FA of about 10. In this study, the top-ranked $20 \%$ of grid cells had FA values greater than 11 (Tables $2 \mathrm{~d}$ and $3 \mathrm{~d}$ ) suggesting that algorithm differences contributed in only a small way to disagreement between these two sets of indexes.

On the ground, spatial disagreements between indexes do not look to be very substantial, even 

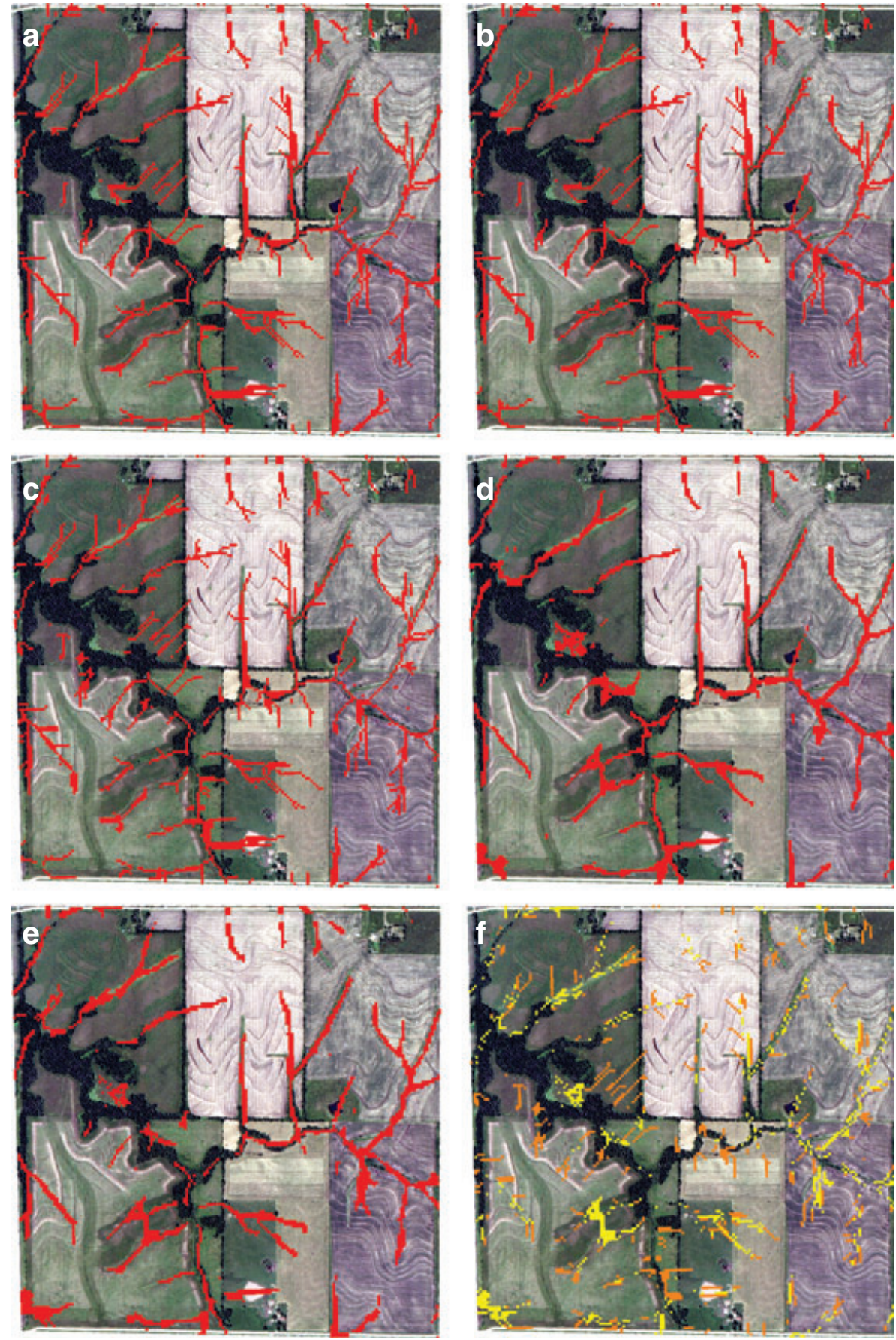

FIGURE 3. Aerial View of a $1 \mathrm{mi}^{2}\left(2.6 \mathrm{~km}^{2}\right)$ Portion of the Cameron-Grindstone Watershed, Missouri, Showing Locations Identified in the Top 10\% of Index Values in That Watershed (in red) Using: (a) FA, (b) WII, (c) SRI, (d) WNI, and (e) TI. Photo (f) shows locations that were identified by TI but not by SRI (in yellow) and identified by SRI but not by TI (in orange).

between TI and SRI which have the lowest correspondence. For example, in the Cameron-Grindstone watershed, both the TI and SRI indexes generally depicted the pattern of the drainage network (Figure 3). However, a closer look at these general locations reveals that the TI index favored flatter bottoms of larger swales, whereas SRI favored steeper slopes along their margins and farther up smaller swales into fields (Figure 3f). Contrast between TI and SRI results was much more pronounced in some portions of the Neshanic watershed than in others. For example, agricultural fields in some areas have low slope and very shallow depth to a restrictive layer (bedrock $<20 \mathrm{in}$ ) which ranked highly by the TI index but not by the SRI (Figure 2f). Elsewhere, restrictive layers under agricultural fields are deeper 
Dosskey, QIU, And Kang

TABLE 5. Site Conditions Favored for Targeting by Each of Five Digital Elevation Models-Based Targeting Indexes.

\begin{tabular}{lcccccc}
\hline Index & Contributing Area & Slope & Soil Texture & Soil Permeability & Soil Depth & Soil Erodibility \\
\hline FA & Large & - & - & - & - & - \\
WNI & Large & Low & - & - & - & - \\
TI & Large & Low & - & Low & Shallow & - \\
WII & Large & - & Line & - & - & High \\
SRI & Large & High & Fine & - & \\
\hline
\end{tabular}

Notes: FA, Flow Accumulation; WNI, Wetness Index; TI, Topographic Index; WII, Water Inflow Index; SRI, Sediment Retention Index.

and the patterns produced by both TI and SRI look similar to that of the natural channel network.

Disagreement between indexes is greater at smaller values of the indexes. Kappa values declined almost universally as smaller index values were included in the comparisons. The highest values in each index are dominated by sites having the very largest contributing areas. For example, the top 5\% of FA values in the Neshanic ranged from 57 to $1,429,396$, but the next lower 5\% increment ranged only from 29 to 56 (Tables $2 \mathrm{a}$ and b). Consequently, contributing source area has a less dominating influence relative to other variables as index values become smaller and this causes cell rankings among the indexes to diverge.

Knowledge of hydrologic circumstances in a watershed is important for selecting a more accurate targeting index for that watershed. Whether runoff from source areas is mainly overland or through the subsurface can have a large influence on the spatial distribution of pollutant loadings and targets for buffers (Lyon et al., 2004, 2006). The WNI and TI would be expected to have greater accuracy where subsurface runoff is the dominant process, whereas WII, SRI, and FA would have greater accuracy where runoff from source areas is primarily overland. The Neshanic watershed has been described as a watershed where subsurface runoff is important (NJDEP, 2011), so WNI and TI might be better suited for this watershed. However, on the agricultural portion (40\%) of this watershed, conversion of forest and pasture to intensive row cropping could increase the likelihood of overland flow from those areas (Frankenberger et al., 1999). In contrast, the Cameron-Grindstone watershed has historically high rates of rill erosion throughout the watershed suggesting that overland runoff is a dominant process. Many watersheds probably have varying mixtures of sites that contribute pollutant load by both processes (Walter et al., 2002, 2003; Zhu et al., 2011). In these watersheds, more effective targeting might involve the use of multiple indexes - one for the subsurface runoff areas and another for the overland runoff areas. This approach, however, would require additional work to spatially identify runoff generation mechanisms on a subwatershed basis.
Knowledge of hydrologic circumstances is also important for proper design of a vegetative buffer. For example, TI indicates precisely where buffer should be installed to prevent mobilization of pollutants, but WII and SRI simply guide the planner to locations where, then, different tools (e.g., Dosskey et al., 2008, 2011a) would be used to properly size a buffer for achieving a desired level of retention of already mobilized pollutants. Furthermore, a buffer for treating sites ranked highly by TI would be designed and managed to stabilize soil and to withhold chemical and manure applications that could become mobilized into overland runoff generated within the buffer (Walter et al., 2000). By contrast, a buffer for treating sites ranked highly by WII and SRI would be designed for the added function of slowing overland runoff flow from source areas and promoting its infiltration and deposition of sediments (Dosskey et al., 2011b). Both types of buffers could remove dissolved pollutants from runoff water in the root zone, whether transported there by subsurface flow or by infiltration of overland flow.

\section{Differences between Watersheds}

Correspondences between indexes were higher across the board in the Cameron-Grindstone watershed than in the Neshanic watershed. This result traces to differences in variability of soil properties between these watersheds. For example, TI and WNI would yield identical rankings if all agricultural soils in a watershed had the same depth and permeability. Increasing variability among soils leads to declining agreement between these indexes. Thus, lower kappa values between TI and WNI in the Neshanic indicate that there is greater soil variability in this watershed than in the Cameron-Grindstone watershed, at least in the areas occupying higher ranking cells. Following this reasoning, soil properties also may vary more in the Neshanic watershed in ways that affect the other indexes, such as in surface soil texture and $\mathrm{K}$ factor. There may also be greater variability in landform factors such as slope and contributing area 
TABLE 6. Digital Data Required to Compute Each of Five Digital Elevation Models-Based Targeting Indexes.

\begin{tabular}{|c|c|c|c|c|c|c|}
\hline \multirow[b]{2}{*}{ Digital Data Layer } & \multirow[b]{2}{*}{ Variable Acquired } & \multicolumn{5}{|c|}{ Index } \\
\hline & & FA & WNI & TI & WII & SRI \\
\hline \multirow[t]{2}{*}{ DEM } & Contributing area & $\sqrt{ }$ & $\sqrt{ }$ & $\sqrt{ }$ & $\sqrt{ }$ & $\sqrt{ }$ \\
\hline & Slope & & $\sqrt{ }$ & $\sqrt{ }$ & & $\sqrt{ }$ \\
\hline \multirow[t]{6}{*}{ SSURGO } & Soil texture class & & & & & $\sqrt{ }$ \\
\hline & $\mathrm{K}$ factor & & & & & $\sqrt{ }$ \\
\hline & $K_{\text {sat }}$ of surface soil layer & & & $\sqrt{ }$ & $\sqrt{ }$ & \\
\hline & $K_{\text {sat }}$ of subsurface soil layers & & & $\sqrt{ }$ & & \\
\hline & Depth to percolation-restricting layer & & & $\sqrt{ }$ & & \\
\hline & Thickness of soil layers & & & $\sqrt{ }$ & & \\
\hline
\end{tabular}

Notes: FA, Flow Accumulation; WNI, Wetness Index; TI, Topographic Index; WII, Water Inflow Index; SRI, Sediment Retention Index; DEM, Different Digital Elevation Models; SSURGO, Soil Survey Geographic.

that might contribute to lower kappa values in the Neshanic watershed. Where greater variability exists within watersheds, more specialized indexes, like TI or SRI, probably would achieve more effective targeting.

\section{Using the Indexes for Targeting Vegetative Buffers}

Spatial patterns revealed by DEM-based targeting indexes provide evidence that water quality impact of vegetative buffers might be improved by employing greater precision in their targeting, and these indexes provide the means for doing so. Traditional locations for buffers have been field margins and the banks (riparian zones) of larger streams in uniformly wide strips. The patterns observed in our study watersheds, however, suggest that field margins and banks of larger streams are often not the best locations for achieving impact with buffers. Our results clearly show that better locations extend well beyond streams into crop fields and do not parallel field margins (Figures 2 and 3). These patterns need to be tested in more and varied watersheds to see how generalizable they are. Planners can also use the targeting indexes both for assessing the effectiveness of existing buffers and for prioritizing locations for future buffer installations. They could also be used as a means to assign water quality credits for buffers by extending more credit to higher ranking locations.

Effective use of DEM-based indexes, however, holds several special challenges for watershed planners. First, the reliability of a DEM-based index depends strongly on the accuracy and resolution of the DEM. In agricultural areas, ditch systems, subsurface drain tiles, road berms, and terraces can be extensive and substantially influence spatial patterns of runoff flow (Souchere et al., 1998; Frankenberger et al., 1999; Dosskey et al., 2003; Hösl et al., 2011; Buchanan et al., 2012). Recent and high-resolution imaging data may be required to detect these features for accurately assessing flow directions, particularly on relatively flatter terrain (Dosskey et al., 2005). Most publically available DEMs have horizontal resolution of 10 or $30 \mathrm{~m}$ and vertical accuracy of about $1.6 \mathrm{~m}$ (Gesch, 2007). Finer grid scales can be produced by resampling, but the accuracy of the topographic information remains unchanged. Many areas are being updated with high-resolution LiDAR or photogrammetric data which produce DEMs having much better accuracy (Xhardé et al., 2006). Alternatively, there are techniques for manually modifying DEMs to account for observed drainage modifications (e.g., Duke et al., 2003; Gironás et al., 2010). Although drainage modifications were observed in the study watersheds, such as terraces visible in the Cameron-Grindstone watershed (Figure 3), no attempt was made in this study to adjust our DEMs for them.

Second, an index value must be determined that defines the upper limit appropriate for a buffer. The largest index values in the study watersheds indicate where stream channels occur and it would be impossible to establish and maintain a functional vegetative buffer in those locations. Therefore, some intermediate value must define the upper limit for targeting buffers. Dosskey et al. (2011b) used aerial photos to visually correlate index values to the presence on the ground of stream channels and grassed waterways. In that study, the lower limit of values corresponding to grassed waterways was considered the upper limit for filter strip-type vegetative buffers. They estimated an upper threshold value for WII and SRI of roughly 400 in the Cameron-Grindstone watershed. More work is needed on the development of threshold values for buffers and on factors that would influence them.

Third, because these indexes are greatly simplified empirical models of watershed processes, they would be better used as guides for planning rather than as strict decision-making tools. These indexes are designed to integrate numerous complex biophysical processes and descriptive variables into simple abstractions for the purpose of making them easy for 
planners to parameterize and apply. Utility of these approximations, however, is gained at the expense of some accuracy. Some loss of accuracy can be avoided by limiting departures from key assumptions, such as by properly matching index to hydrologic circumstances and by ensuring DEM accuracy. The planner will need to judge how any departures from these and other assumptions might affect interpretation of index results for a given watershed.

Fourth, planners must weigh the relative advantages and disadvantages of each index on a watershed by watershed basis. A more accurate choice would be an index that more closely matches the runoff hydrology of the area. Among other considerations, WII and SRI provide scaled and quantitative estimates of volume of runoff (WII) and mass of sediment retained (SRI) that may be useful for credit valuation and TMDL planning purposes, whereas WNI and TI are unscaled, relativistic indexes. The WII and SRI can also be used to compare locations across different climate regions. Simpler models, however, are easier for planners to use. Among DEM-based indexes, FA would be the easiest to use, closely followed by WNI because they employ only the DEM (Table 6). The remaining indexes, TI, WII, and SRI additionally require acquisition and processing of SSURGO data. Of these, TI may be more difficult to use because it contains the most variables to parameterize and because it is left to the user to judge, rather than to simply copy, from SSURGO the presence and depth of a soil layer that is sufficiently percolation restricting, a task which can be difficult where there are deep, fine-textured subsoils.

\section{CONCLUSIONS}

Five different DEM-based models were compared and contrasted for their utility in targeting vegetative buffers for greater water quality effectiveness in agricultural watersheds. The indexes compared included: Flow Accumulation, Wetness Index, Topographic Index, Water Inflow Index, and Sediment Retention Index. For the comparisons, the indexes were applied to two watersheds, one in Missouri and the other in New Jersey. The results showed that they tend to target similar locations because all of them emphasize the importance of intercepting runoff from larger source areas to the mitigation potential of vegetative buffers. The use of DEMs enables identifying runoff patterns at a fine scale of resolution necessary for addressing agricultural runoff with buffers. All of them provide standardized bases for making targeting decisions. Although DEM-based indexes promise greater spatial precision and accuracy than categori- cal targeting models such as agricultural fields, riparian zones, or wetlands, there are special challenges to using them, including: ensuring DEM data accuracy; selecting an index that matches the hydrologic circumstances; developing upper threshold index values for the appropriateness of vegetative buffers; and handling greater model complexity.

\section{ACKNOWLEDGMENTS}

The authors thank Todd Kellerman, USDA National Agroforestry Center for his assistance with GIS processing. This study was funded, in part, by funds provided by the US Forest Service, Southern Research Station, USDA National Agroforestry Center through a grant to the New Jersey Institute of Technology.

\section{LITERATURE CITED}

Beaulac, M.N. and K.H. Reckhow, 1982. An Examination of Land Use-Nutrient Export Relationships. Water Resources Bulletin 18:1013-1024.

Buchanan, B.P., K. Falbo, R.L. Schneider, Z.M. Easton, and M.T. Walter, 2012. Hydrological Impact of Roadside Ditches in an Agricultural Watershed in Central New York: Implications for Non-Point Source Pollutant Transport. Hydrological Processes. http//dx.doi.org/10.1002/hyp.9305.

Burkart, M.R., D.E. James, and M.D. Tomer, 2004. Hydrologic and Terrain Variables to Aid Strategic Location of Riparian Buffers. Journal of Soil and Water Conservation 59:216-223.

Dillaha, T.A., R.B. Reneau, S. Mostaghimi, and D. Lee, 1989. Vegetative Filter Strips for Agricultural Nonpoint Source Pollution Control. Transactions of the American Society of Agricultural Engineers 32:513-519.

Dosskey, M., M. Helmers, D. Eisenhauer, T. Franti, and K. Hoagland, 2003. Hydrologic Routing of Farm Runoff and Implications for Riparian Buffers. In: Agricultural Hydrology and Water Quality, J.D. Williams and D. Kolpin (Editors). American Water Resources Association, Middleburg, Virginia, p. 4. TPS-03-1.

Dosskey, M.G., D.E. Eisenhauer, and M.J. Helmers, 2005. Establishing Conservation Buffers Using Precision Information. Journal of Soil and Water Conservation 60:349-354.

Dosskey, M.G., M.J. Helmers, and D.E. Eisenhauer, 2006. An Approach for Using Soil Surveys to Guide the Placement of Water Quality Buffers. Journal of Soil and Water Conservation 61:344-354.

Dosskey, M.G., M.J. Helmers, and D.E. Eisenhauer, 2008. A Design Aid for Determining Width of Filter Strips. Journal of Soil and Water Conservation 63:232-241.

Dosskey, M.G., M.J. Helmers, and D.E. Eisenhauer, 2011a. A Design Aid for Sizing Filter Strips Using Buffer Area Ratio. Journal of Soil and Water Conservation 66:29-39.

Dosskey, M.G., M.J. Helmers, D.E. Eisenhauer, T.G. Franti, and K.D. Hoagland, 2002. Assessment of Concentrated Flow Through Riparian Buffers. Journal of Soil and Water Conservation 57:336-343.

Dosskey, M.G., Z. Qiu, M.J. Helmers, and D.E. Eisenhauer, 2011b. Improved Indexes for Targeting Placement of Buffers of Hortonian Runoff. Journal of Soil and Water Conservation 66:362372.

Duke, G.D., S.W. Kienzie, D.L. Johnson, and J.M. Byrne, 2003. Improving Overland Flow Routing by Incorporating Ancillary 
Road Data into Digital Elevation Models. Journal of Spatial Hydrology 3:1-27.

Easton, Z.M., M.T. Walter, and T.S. Steenhuis, 2008. Combined Monitoring and Modeling Indicates the Most Effective Agricultural Best Management Practices. Journal of Environmental Quality 37:1798-1809.

Fleiss, J.L., B. Levin, and M.C. Paik, 2003. Statistical Methods for Rates and Proportions (Third Edition). Wiley-Interscience, New York, 760 pp., ISBN-13: 978-0471526292.

Frankenberger, J.R., E.S. Brooks, M.T. Walter, M.F. Walter, and T.S. Steenhuis, 1999. A GIS-Based Variable Source Area Hydrology Model. Hydrological Processes 13:805-822.

Fry, J., G. Xian, S. Jin, J. Dewitz, C. Homer, L. Yang, C. Barnes, N. Herold, and J. Wickham, 2011. Completion of the 2006 National Land Cover Database for the Conterminous United States. Photogrammetric Engineering and Remote Sensing 77:858-864.

Gesch, D.B., 2007. The National Elevation Dataset. In: Digital Elevation Model Technologies and Applications: The DEM Users Manual, D. Maune (Editor). American Society for Photogrammetry and Remote Sensing, Bethesda, Maryland, pp. 61-82, ISBN13: 978-1570830822.

Gironás, J., J.D. Niemann, L.A. Roesner, F. Rodriguez, and H. Andrieu, 2010. Evaluation of Methods for Representing Urban Terrain in Storm-Water Modeling. Journal of Hydrologic Engineering 15:1-14.

Hösl, R., P. Strauss, and T. Glade, 2011. Man-Made Linear Flow Paths at Catchment Scale: Identification, Factors and Consequences for the Efficiency of Vegetated Filter Strips. Landscape and Urban Planning 104:245-252.

Jenson, S.K. and J.O. Domingue, 1988. Extracting Topographic Structure from Digital Elevation Data for Geographic Information System Analysis. Photogrammetric Engineering and Remote Sensing 54:1593-1600.

Lyon, S.W., P. Gérard-Marchant, M.T. Walter, and T.S. Steenhuis, 2004. Using a Topographic Index to Distribute Variable Source Area Runoff Predicted with the SCS-Curve Number Equation. Hydrological Processes 18:2757-2771.

Lyon, S.W., M.R. McHale, M.T. Walter, and T.S. Steenhuis, 2006. The Impact of Runoff Generation Mechanisms on the Location of Critical Source Areas. Journal of the American Water Resources Association 42:793-804.

MDNR (Missouri Department of Natural Resources), 2004. Total Daily Maximum Load Information Sheet: Cameron Lakes. Water Protection Program, Jefferson City, Missouri. http://www. dnr.mo.gov/env/wpp/tmdl/info/, accessed September 2012.

Moore, I.D., R.B. Grayson, and A.R. Ladson, 1991. Digital Terrain Modelling: A Review of Hydrological, Geomorphological, and Biological Applications. Hydrological Processes 5:3-30.

Muñoz-Carpena, R. and J.E. Parsons, 2012. VFSMOD-W: Vegetative Filter Strip Modeling System, Model Documentation and User's Manual, Version 6.x. University of Florida, Gainesville, Florida. http://abe.ufl.edu/carpena/vfsmod/, accessed September 2012.

Nigh, T.A. and W.A. Schroeder, 2002. Atlas of Missouri's Ecoregions. Missouri Department of Conservation, Jefferson City, Missouri, $212 \mathrm{pp}$.

NJDEP (New Jersey Department of Environmental Protection), 2008. The 2008 New Jersey Integrated Water Quality Monitoring and Assessment Report (Draft). Water Monitoring and Standards, Bureau of Water Quality Standards and Assessment, NJDEP. http://www.state.nj.us/dep/wms/bwqsa/draft_2008_integrated_report.pdf, accessed September 2012.

NJDEP (New Jersey Department of Environmental Protection), 2010. Surface Water Quality Standards, N.J.A.C. 7:9B, amended January 4, 2010 (42 N.J.R. 68(a)). http://www.nj.gov/dep/rules/ rules/njac7_9b.pdf, accessed September 2012.
NJDEP (New Jersey Department of Environmental Protection), 2011. The Neshanic River Watershed Restoration Plan. Office of Policy Implementation and Watershed Restoration, Trenton, New Jersey. Prepared by the Department of Chemistry and Environmental Science, New Jersey Institute of Technology, Newark, New Jersey. http://ims.njit.edu/neshanic/project/plandocuments.html, accessed September 2012.

NJWSA (New Jersey Water Supply Authority), 2002. Raritan Basin Watershed Management Plan. The Watershed Protection Unit, NJWSA. http://www.raritanbasin.org/, accessed September 2012.

NRCS (Natural Resources Conservation Service), 2012. Filter Strip Code 393. In: National Handbook of Conservation Practices. USDA Natural Resources Conservation Service, Washington, D.C. http://www.nrcs.usda.gov/technical/standards/nhcp.html, accessed September 2012.

Pankau, R.C., J.E. Schoonover, K.W.J. Williard, and P.J. Edwards, 2012. Concentrated Flow Paths in Riparian Buffer Zones of Southern Illinois. Agroforestry Systems 84:191-205.

Qiu, Z., 2003. A VSA-Based Strategy for Placing Conservation Buffers in Agricultural Watersheds. Environmental Management 32:299-311.

Qiu, Z., 2009. Assessing Critical Source Area in Watersheds for Conservation Buffer Planning and Riparian Restoration. Environmental Management 44:968-980.

Rawls, W.J. and D.L. Brakensiek, 1983. A Procedure to Predict Green-Ampt Infiltration Parameters. In: Advances in Infiltration, Publication No. 11-83, American Society of Agricultural Engineers, St. Joseph, Michigan, pp. 102-112.

Renard, K.G., G.R. Foster, G.A. Weesies, D.K. McCool, and D.C. Yoder (Coordinators), 1997. Predicting Soil Erosion by Water: A Guide to Conservation Planning with the Revised Universal Soil Loss Equation (RUSLE). Agriculture Handbook No. 703. U.S. Department of Agriculture, Washington, D.C., 384 pp., ISBN13: 978-1060489389.

Rosenblatt, A.E., A.J. Gold, M.H. Stolt, P.M. Groffman, and D.Q. Kellogg, 2001. Identifying Riparian Sinks for Watershed Nitrate Using Soil Surveys. Journal of Environmental Quality 30:15961604.

Schneiderman, E.M., T.S. Steenhuis, D.J. Thongs, Z.M. Easton, M.S. Zion, A.L. Neal, G.F. Mendoza, and M.T. Walter, 2007. Incorporating Variable Source Area Hydrology into a CurveNumber-Based Watershed Model. Hydrological Processes 21:3420-3430.

Souchere, V., D. King, J. Daroussin, F. Papy, and A. Capillon, 1998. Effects of Tillage on Runoff Directions: Consequences on Runoff Contributing Area within Agricultural Catchments. Journal of Hydrology 206:256-267.

Tarboton, D.G., 1997. A New Method for the Determination of Flow Directions and Upslope Areas in Grid Digital Elevation Models. Water Resources Research 33:309-319.

Tarboton, D.G., 2005. Terrain Analysis Using Digital Elevation Models (TauDEM), Version 3.1. Utah State University, Logan, Utah. http://hydrology.usu.edu/taudem/taudem5.0/index.html, accessed September 2012.

Tomer, M.D., D.E. James, and T.M. Isenhart, 2003. Optimizing the Placement of Riparian Practices in a Watershed Using Terrain Analysis. Journal of Soil and Water Conservation 58:198-206.

Walter, M.T., V.K. Mehta, A.M. Marrone, J. Boll, P. GérardMarchant, T.S. Steenhuis, and M.F. Walter, 2003. Simple Estimation of Prevalence of Hortonian Flow in New York City Watersheds. Journal of Hydrologic Engineering 8:214-218.

Walter, M.T., T.S. Steenhuis, V.K. Mehta, D. Thongs, M. Zion, and E. Schneiderman, 2002. A Refined Conceptualization of TOPMODEL for Shallow-Subsurface Flows. Hydrological Processes 16:2041-2046.

Walter, M.T., M.F. Walter, E.S. Brooks, T.S. Steenhuis, J. Boll, and K. Weiler, 2000. Hydrologically Sensitive Areas: Variable 
Source Area Hydrology Implications for Water Quality Risk Assessment. Journal of Soil and Water Conservation 55:277284.

Walter, T., M. Dosskey, M. Khanna, J. Miller, M. Tomer, and J. Wiens, 2007. The Science of Targeting within Landscapes and Watersheds to Improve Conservation Success. In: Managing Agricultural Landscapes for Environmental Quality: Strengthening the Science Base, M. Schnepf and C. Cox (Editors). Soil and Water Conservation Society, Ankeny, Iowa, pp. 63-89, ISBN-13: 978-0976943242.

Welsch, D.J., 1991. Riparian Forest Buffers: Function and Design for Protection and Enhancement of Water Resources. NA-PR-0791. USDA Forest Service, Northeastern Area State \& Private Forestry, Radnor, Pennsylvania, $20 \mathrm{pp}$.

Xhardé, R., B.F. Long, and D.L. Forbes, 2006. Accuracy and Limitations of Airborne LiDAR Surveys in Coastal Environments. In: Proceedings of the 2006 International Geoscience and Remote Sensing Symposium, IEEE, New York City, New York, pp. 2412-2415, ISBN: 0-7803-9510-7.

Zhu, Q., J.P. Schmidt, and R.B. Bryant, 2011. Hot Moments and Hot Spots of Nutrient Losses from a Mixed Land Use Watershed. Journal of Hydrology 414-415:393-404. 